\title{
Developing Intercultural Communicative Competence in ELF Communication
}

\begin{abstract}
The traditional notion of English as a foreign language solely for communicating with native speakers can no longer be applied in a world that is constantly changing, hence paving the way for an alternative use of the language known as English as a lingua franca. As a result, instead of focusing only on grammatical correctness, research into language pedagogy has also come to recognize the importance of exploring bottom-up learning processes, and developing intercultural communicative competence (ICC) and more communicative-based methods. Nowadays, it is essential to acquire the knowledge, skills, attitudes and critical cultural awareness necessary to communicate successfully. To show the importance of integrating ICC in language pedagogy, a recording from the Vienna-Oxford International Corpus of English is analysed here to demonstrate the significance of developing critical awareness as well as several communicative strategies, so that language learners can afterwards have the necessary ICC to interact in today's multi-lingual/cultural society.
\end{abstract}

Keywords: English as a lingua franca; intercultural communicative competence; communicative strategies

\section{Razvijanje medkulturne komunikacijske kompetence $v$ sporazumevanju $v$ angleščini kot lingvi franki}

\section{POVZETEK}

Tradicionalni koncept angleščine kot tujega jezika za sporazumevanje izključno z maternimi govorci ni več uporaben v svetu, ki se nenehno spreminja in tako tlakuje pot alternativni rabi tega jezika, znani kot angleščina kot lingva franka. Namesto osredotočanja samo na slovnično pravilnost zato raziskovanje jezikovne didaktike danes prepoznava pomen preučevanja učnih procesov od spodaj navzgor ter razvijanja medkulturne komunikacijske kompetence (MKK) in metod, ki temeljijo na sporazumevanju. Dandanes je bistvenega pomena usvajanje znanja, spretnosti, stališč in kritične kulturne zavesti, ki so nujni za uspešno sporočanje. Kot ponazoritev pomembnosti vključevanja MKK v jezikovno didaktiko predstavi članek analizo posnetka iz korpusa ViennaOxford International Corpus of English, ki jasno pokaže pomen razvijanja kritične zavesti in nabora komunikacijskih strategij, ki učencem omogočajo MKK, nujno za delovanje v današnji večjezični/večkulturni družbi.

Ključne besede: angleščina kot lingva franka; medkulturna komunikacijska kompetenca; komunikacijske strategije 


\section{Developing Intercultural Communicative Competence in ELF Communication}

\section{Introduction}

Advances in technology, be they telecommunications, the Internet, or transportation, have greatly contributed to the increasing number of interactions taking place between people of different language and cultural backgrounds in ways and for reasons that were greatly unthinkable just a few decades ago. This interconnectedness has not only affected our daily lives, but has also triggered the need to encounter a collective voice so as to overcome the linguistic difficulties that may arise in contact. As a result, this relatively recent and diverse reality has contributed to the development of new 'emerging' language repertoires resulting from the immediate processes of language contact generated by specific communicative needs.

The English language has therefore played an essential role in creating a 'common voice' shared by the great majority of the world's population, firstly due to the British expansion around the world in the seventeenth century and then because of the role the United States of America has played throughout the twentieth and twenty-first centuries in globalization and in the dissemination of its culture, with cinema and music being readily accessible to all. Accordingly, English has come to be the most prevailing global lingua franca. Many changes, however, have been verified in how the language is used. Graddol $(2006,11)$ draws our attention to the fact that it is no longer "English as we have known it, and have taught it in the past as a foreign language" but "a new phenomenon" known as English as a Lingua Franca (ELF). ${ }^{1}$

Considering the notion of ELF, I will firstly discuss how it differs from the traditional concept of English as a Foreign Language (EFL), so as to better understand the consequences that its current use worldwide may have on English language teaching (ELT); afterwards, I will reflect on the ever increasing role intercultural communicative competence (ICC) plays in international and intranational interactions in English as well as pedagogically; lastly, I will exemplify the importance of fostering ICC in ELF interactions, in particular by analysing a short excerpt taken from VOICE, the Vienna-Oxford International Corpus of English (2005-2013), where it is visible that critical awareness and communicative strategies are important in achieving effective communicative competence in today's multilingual and multicultural society.

\section{EFL vs. ELF and Its Implications}

The contexts of ELF use are many, various and familiar, and they include everyday exchanges amongst travellers, academic/scientific discussions at international conferences, and communication in politics and diplomacy at an international level. In fact, according to Kachru's concentric circle model (1985), what at first was the national language in Inner circle countries (for instance, in the United Kingdom and the United States) has grown to become the first true lingua franca worldwide. In addition to the Inner circle, Kachru's model also consists of two other circles, the Outer and Expanding circles. While the former consists of countries that are a part of the global Englishes paradigm and that are characterized as being multilingual, that is, using English as a second language (in India or Singapore, for instance), the latter refers to countries where English is

For a more detailed description of the increasing number of non-native English speakers and how English is changing at a demographical, economic, technological and societal level, see Graddol (2006). 
traditionally learnt as a foreign language (in Portugal, Brazil and China, to name a few). It is these Outer and Expanding circle communities that have especially been the object of study of current ELF use.

With these contexts in mind, Firth $(1996,240)$ states that ELF is "a 'contact language' between persons who share neither a common native tongue nor a common (national) culture and for whom English is the chosen foreign language of communication." And yet the majority of ELF researchers have not accepted this definition, as it excludes a crucial aspect in ELF interaction, the inclusion of native English speakers. At the time, Firth's aim was to explain how speakers with a low proficiency could often use English successfully in lingua franca communication. However, the comparison established lay essentially between a defective type of 'foreigner' English and a native speaker English standard, as opposed to considering ELF as a distinct type of English, in which its users are usually proficient with greatly developed skills.

The VOICE corpus website, on the other hand, presents a more current and basic definition of ELF describing it as the "English used as a common means of communication among speakers from different first-language backgrounds" (VOICE. Vienna-Oxford International Corpus of English 2005-2013). From this perspective, native speakers of English are no longer excluded. However, they also do not take on the customary role of norm providers. Furthermore, seeing that ELF is viewed as an acquired system to interact effectively in multilingual and multicultural settings, native speakers cannot necessarily use their own native English in every circumstance. Thus, ELF can be described functionally according to its use in intercultural interactions, instead of formally by its reference to native-speaker norms, as Hülmbauer, Böhringerm, and Seidlhofer (2009, 27) believe:

Speakers of any L1 can appropriate ELF for their own purposes without over-deference to native-speaker norms. This counteracts a deficit view of lingua franca English in that it implies equal communicative rights for all its speakers. So defined, ELF is emphatically not the English as a property of its native speakers, but is democratized and universalized in the 'exolingual' process of being appropriated for international use.

Widdowson $(1994,385)$ also further states native speakers have "no right to intervene or pass judgment $[\ldots]$ The very fact that English is an international language means that no nation can have custody over it."

Moreover, it is imperative to stress that, for many researchers in ELF, EFL and ELF are two phenomena that can be clearly distinguished. Jenkins (2011), for instance, briefly describes these two concepts in terms of paradigms, perspectives, metaphor, as well as code-mixing and codeswitching. EFL is a part of the modern foreign languages paradigm, in which English language learning does not diverge from learning other foreign languages and where the aim is to achieve near-native competence. In contrast, ELF is integrated in the global Englishes paradigm, where all types of Englishes are considered unique, not failed attempts to assimilate to a specific native speaker variety. For this reason, ELF adopts a difference perspective in comparison to EFL, which takes on a deficit perspective. In this sense, from an ELF outlook, variances from native speaker English are deemed as valid alternatives, whereas in EFL they are judged as mistakes. This being said, ELF users cannot necessarily always be regarded as proficient. There are cases in which they continue to be learners. However, there are also others in which the learning process has ended without them ever reaching a proficient level of English, and in these cases, variations are considered errors. Although it may not seem clear at times, there exists a sociolinguistic difference 
between ELF learners' mistakes and competent ELF users' innovations, even though occasionally the two may lead to similar forms. Furthermore, Jenkins (2011) also refers to how metaphorically ELF is associated with language contact and evolution, in contrast with EFL, which is connected with interference and fossilization. Lastly, code-mixing and code-switching are both viewed as useful pragmatic strategies for bilinguals. In EFL, meanwhile, they indicate gaps in knowledge. ${ }^{2}$

Considering these notions, ELF can be viewed as a use of English, while EFL is mainly associated with a pedagogic subject. In other words, while ELF is mainly used in intercultural contexts, EFL continues to be taught in the majority of schools in Expanding circle countries, where native speakers are considered the ultimate aim to be achieved, and where native English speaker culture is also encompassed. In one particular situation a person can be in the position of an EFL user, while on another occasion, they can be an ELF user, all depending on the situation and the person with whom they are speaking with and for what purpose (Hülmbauer, Böhringer, and Seidlhofer 2009).

Given the transformation in the function and use of English worldwide, current views on language teaching have likewise been greatly affected. ELT traditionally based on the notion of English as a foreign language, which mainly "highlights the importance of learning about the culture and society of native speakers; [...] the centrality of the methodology in discussions of effective learning; and [...] the importance of emulating native speaker language behaviour" (Graddol 2006, 82), has given way not only to a greater socio-political awareness, but also to intercultural awareness.

Furthermore, while previously teachers were generally educated on the several approaches to description and instruction of 'proper' language, currently, there is a much wider diversity of concerns that demand at least as much attention as language proper. These issues have led to a wider conception in ELT discourse in which notions of correctness, norms, mistakes and authority have gone on to include also notions of a transformative pedagogy, learner-centeredness, awareness as well as (self-)reflection (Pennycook 1999), all depending on the learners' aims.

By abandoning this seemingly unrealistic notion of 'native-like' proficiency, ELT can concentrate on other skills and procedures deemed equally valuable in ELF exchanges. There have been several communication strategies and accommodation skills (Jenkins 2000) identified in order to characterize ELF interactions, of which the following may be included: assessing interlocutors' linguistic repertoires, resorting to extralinguistic cues, supportive listening, indicating noncomprehension in a face-saving way, paraphrasing, requesting repetition, self-repair, backchannelling, confirmation, in addition to the clarification of requests that allow participants to check, monitor and clarify understanding, among other skills (Mauranen 2006; Seidlhofer 2002). Furthermore, contact with a wide array of varieties of English, along with a multilingual/comparative approach, equally contributes to facilitating the acquisition of the communicative abilities.

In this sense, it may be argued that an ELF approach is more susceptible to the development of pragmatic ability, seeing that communicative competence among learners/users is intimately linked with the negotiation of meaning. This is especially the case when English is used among a diverse group of speakers, where flexibility and the ability to adjust are essential (Erling 2004, 251), when compared to foreign language knowledge, which focuses mainly on the acquisition of a strictly idealized norm, with particular emphasis on phonological, morphological, syntactic and semantic forms. The aim then is centred on the process of learning rather than on the intended product (Perrett 2000).

For further reflections on English as a lingua franca see Jenkins (2000, 2007); Mauranen and Ranta (2009); and Seidlhofer (2011). 


\section{ELF and (Intercultural) Communicative Competence}

In light of what has been discussed about ELF, the importance of achieving effective communicative competence is clearly central in ELF interactions, as well as in language pedagogy, where awareness raising and pluricentricity are called upon. As Canagarajah $(2005,25)$ states, "new competencies [are] required for communication and literacy in today's world" and therefore, a single dialect of English "fails to equip our students for real-world needs." For this reason, the need to obtain communicative competence is imperative in both sociolinguistics and in pedagogical theory, where approaches solely concerned with grammatical correctness have given way to additional aspects of communicative effectiveness where the status quo of native speaker communicative competence might no longer be the most appropriate in international scenarios; hence, proposing notions like appropriateness, acceptability and intelligibility as relative notions in English pedagogy (Berns 2006).

In what concerns communicative competence, presently, the relationship between language, and society and culture is a deep-rooted construct. It is worth noting that the notion of communicative competence has taken into consideration two linguistic traditions: Hymes' ethnography of communication (1962, 1972) and Halliday's systemic-functional paradigm (1978). These contributions, despite being distinctive, complement the use of communicative competence as a theoretical paradigm in World Englishes studies (Berns 2006) and henceforth in ELF studies as well, which is part of the World Englishes paradigm.

Even though Hymes is attributed with presenting communicative competence as a linguistic concept in the early 1970s, it was J. R. Firth who had, some forty years before, already underlined the importance of context of situation, describing it as the particular communicative competence associated with each individual speaker who has grown in Expanding circle settings, for instance. Berns $(2006,719)$ sums up Firth's view (1930) by stating that "only through the inclusion of context of situation as a parameter for determining what communicative competence means do the pluralistic nature of a language and the independent existence and the dynamic creative processes of non-native varieties come into focus." This junction between the cultural and social components of communication later had an important impact on both Hymes and Halliday.

It is Hymes who coined the term communicative competence, as the ability users of a language have to choose what to say in addition to when and how it may be said, given that the situational context inevitably influences their linguistic performance. As Hymes (1980, vi) states, "social life shapes communicative competence."

Halliday (1978), on the other hand, considers the part of the social context and the choices language users need to make in order to do things with language in a particular context. He refers to the alternatives presented in each situation as meaning potential, in other words, the choices (either pragmatic, phonological or lexical) language users have for conveying, understanding and negotiating meaning among each other. These appropriate local choices and selections made by users in specific situations are centred on the restrictions of their systemic knowledge, and as Halliday and Mathiessen $(2004,23)$ note, "a language is a resource for making meaning, and meaning resides in systemic patterns of choice."

Given people's diverse linguistic and cultural backgrounds, communicative competence in lingua franca use will inevitably stress the importance of intercultural sensitivity. In addition to the interlocutor's cultural background, which needs to be taken into consideration, so does the cultural context as well as the cultural indications transmitted by the language employed, as is stated by Mauranen $(2005,274)$ : "The contexts of use lingua franca speakers experience typically 
involve interaction with people from highly diverse backgrounds. This requires constant intercultural sensitivity to a degree not normally experienced by mono- or even bilingual speakers in their native languages."

Perhaps a global definition of communicative competence at an international level may be that when communicating, competence is a universal and worldwide concept incorporating several interconnecting factors (such as discourse, intercultural, interpersonal, linguistic, pragmatic, and strategic) of exploitable knowledge, and the necessary skills and abilities to apply them in a range of societies as well as types of societies (Nunn 2007, 43). This competence not only includes spoken and written language skills, but also creativity and specific adaptive skills, like knowing how to negotiate meaning in a variety of different contexts.

It is worth noting though that total competence is beyond anyone's range. However, competent users are able to compensate for weaknesses in one particular area with the knowledge or skill in another, such as using a widely intelligible variety of English that may be adapted accordingly in awareness of the necessary requirements in intercultural scenarios, in which there may be several stages of proficiency and varied needs. Nunn $(2007,43)$ further reiterates the importance of competent speakers negotiating norms in order to achieve effective communication: "No one global standard will fit all users and communities but all competent users will have enough in common to be able to negotiate norms and interim norms in order to communicate successfully within and between particular communities and sub-communities."

Nunn $(2007,41)$ considers the significance of several essential aspects for communicative competence at an international level, namely: multiglossic, in which it is necessary for speakers to be sensitive not only to diverse identities, but also to be capable of intelligibly conveying their own identity; strategic, communicative strategies are vital and cooperative factors in intercultural ELF interactions; pragmaticldiscourse, being able to adapt language according to the situation and solving differences of background knowledge, therefore preparation is required; and lastly, intercultural, in the sense of being able to adjust to unpredictable multicultural situations, rather than being familiar with solely a single culture for effective cross-cultural communication, for instance.

\section{A Study from the VOICE Corpus}

With roughly 1,250 proficient speakers of ELF from about fifty distinctive first languages, VOICE, the Vienna-Oxford International Corpus of English (2005-2013), is a structured collection of language data capturing spoken ELF interactions, containing transcriptions of spontaneous, non-scripted face-to-face communication in international scenarios. The captured speech events conform to a number of conditions, namely, that it is ELF (most of the speakers come from different linguistic backgrounds and use English as a shared means of communication; in addition, the majority speak it as an additionally learnt idiom), spoken, naturally occurring, non-scripted, collaborative, face-to-face, and lastly, it is based on self-selected participation (for instance, interlocutors are the ones who make the decision whether they are able to use ELF to achieve certain participant tasks in the situations they partake in).

Upon analysing in detail the VOICE corpus, many are the examples of communication strategies and accommodation skills which play a part in achieving effective communicative competence in ELF interactions. The following extract will be used to corroborate and exemplify the importance of various communicative strategies suggested by Jenkins (2000), Mauranen (2006), and Seidlhofer (2002), namely, backchannelling, the negotiation of meaning, repetition and self-repair. 
The conversation reported below belongs to the educational domain (transcript EDcon4 taken from the VOICE corpus) and it took place at a cafe on campus during an international summer school course. It is a conversation between a Polish female (S1) and a Romanian male (S2), each between the ages of 17 and 24. They are discussing what happened at a party the night before, in which $S 1$ had a little too much to drink and she is now trying to explain to S2 the specifications of a game she played.

Extract $1 .^{3}$

1S1: and $<@>$ the problem was $</ @>$ that she was like

$2 \quad$ running

3S2: @@@

$4 \quad$ S1: the whole city and $\mathrm{i}$ was like (.)

5S2:@@@

$6 \quad$ S1: I'll be back and we saw the people because

7 the people were so smart (.) that they didn't

8 find the answer. (.) but they went to the tourist

910 office $<@>$ and they asked for answers. $<$ @ $>$ (.)

10 S2: okay

11 S1: and they gave

12 S2: AH because they had to complete some erm

13 S1: $\mathrm{mhm}$

14 S2: okay

15 S1: how tall is the the tower o:r (.)

16 S2: the tower? (.)

17 S1: yeah the the the church tower and er how old

18 was the guy who died here and he was the founder

19 of the city (.)

20 S2: was he was his name [last name2]? (.)

21 S1: no

22 S2: mister [last name2]

23 S1: i don't know because i skipped few questions (.)

24 i didn't participate actively @ (.)

25 S2: okay (2) so erm [first name3] was not upset (.)

26 [first name3] (.)

3 The mark-up conventions follow the 2.1 VOICE transcript conventions, which may be fully accessed on the VOICE corpus website. For instance, brief pauses are marked with a full stop in between parentheses (.), laughter is represented with the @ symbol and when reference is made to other names these are usually anonymized by [name1]. 
27 S1: about what (.)

28 S2: he was not upset? (1)

29 S1: about (.)

30 S2: that (.) you didn't participate. (.)

31 S1: well i (.) i went there i was physically there@@

$32 \quad \mathrm{~S} 2: \mathrm{mhm}$

33 S1: only physically. (.)

34 S2: Mhm

35 S1: not mentally (1)

36S2:@@

A frequent interactional feature in conversations, as is visible in this particular exchange, is the use of backchannelling and resorting to positive minimal feedback. This is especially the case when S2 acknowledges S1's humorous tone of the turn by laughing at the story being told (11. 3, 5, and 36), or also by repeating the word 'okay' frequently (1l. 10, 14, and 25), as well as by manifesting non-verbal acknowledgement tokens like 'mhm' (ll. 13, 32, and 34).

Although it may not seem essential, in general terms, backchannelling plays an important part in discussions, as verbal and non-verbal utterances (e.g., mhm, uh huh, yea, right), head nods and smiles are ways through which listeners may signal they are paying attention to what is being said, and they want the speaker to continue to talk. This is in addition to it being used as well as a sign of ensuring the efficiency of the communication. Instead of simply relying on correct language use for understanding and receiving messages, backchannels are also vital to "indicate that a piece of talk by the speaker has been registered by the recipient of that talk" (Gardner 2001, 13) as well as to "help the current speaker along while manifesting the listener's attention" (Stenström 1994, 81).

In line with the above, the negotiation of meaning is also a fundamental part in any interaction, as can be exemplified by both interlocutors in the excerpt, who resort to the negotiation of meaning between lines 23 and 30, where it is visible that S2 seems to have forgotten to make it clear to $\mathrm{S} 1$ what the topic of the question is. Through repetition, signalling non-comprehension and paraphrasing (1. 24 "I didn't participate actively," 1. 30 "that you didn't participate") the intended message is clarified in the end, making it evident that the question is about whether someone had been disappointed with S1 not participating.

(1)

$\begin{array}{lll}23 & \text { S1: } & \text { i don't know because i skipped few questions (.) } \\ 24 & & \text { i didn't participate actively @ (.) } \\ 25 & \text { S2: } & \text { okay (2) so erm [first name3] was not upset (.) } \\ 26 & & \text { [first name3] (.) } \\ 27 & \text { S1: } & \text { about what (.) } \\ 28 & \text { S2: } & \text { he was not upset? (1) } \\ 29 & \text { S1: } & \text { about }(.) \\ 30 & \text { S2: } & \text { that }(.) \text { you didn't participate. }(.)\end{array}$


However, it is important to mention that various researchers have judged the use of repetition in interactions as an indication of incoherence, uncertainty, and flawed language use (for instance Scollon and Scollon 2001), whereas others (for instance Halliday and Hasan 1976; Tannen 1989) view it as a fundamental and cohesive factor in communication. As an accommodation strategy, repetition plays a key role, as it may simultaneously function in production, comprehension, connection, and interaction in order to make what someone says more accessible.

In this specific example, repetition is visible in lines 15,16 , and 17 concerning the word 'tower', where S1 asks about the height of the tower and S2 inquires - "the tower?" - and S1 hesitantly responds (repeating the article 'the' three times) clarifying and specifying the particular tower she is referring to, "the church tower." The primary concern of the speakers here appears to be that of convergence of both the intended and received message, so as to avoid any further breakdown in communication.
15 S1: how tall is the the tower o:r (.)
16 S2: the tower? (.)
17 S1: yeah the the the church tower and er how old

Repetition may likewise be used to emphasise and clarify who or what is being referred to. This can be observed with S2's self-repetition, when he repeats at the end of his turn the person he is mentioning (11. 25-26).

(3)

$$
\begin{array}{lll}
25 & \text { S2: } & \text { okay (2) so erm [first name3] was not upset (.) } \\
26 & \text { [first name3] (.) }
\end{array}
$$

As for self-repair, it is equally part of effective communication. It allows interlocutors to rethink and restructure their message in order to make it clearer and more intelligible for the other speaker; in other words, being sensitive enough to measure the situation so as to prevent misunderstandings. By rephrasing, interlocutors are able to change their wording so as to adjust the initial formulation, correct it (either syntactically or lexically, for instance), and make it more understandable, or it may even be used for placing emphasis on a certain issue. When this occurs at the beginning of a turn, it may also be confused with false starts, which is a normal part of oral discourse. Even though these issues are usually associated with non-native speakers and therefore considered a problem that ought to be eliminated, Mauranen $(2012,213)$ believes that they actually have a valuable role (similarly to repeats), as they offer a respite "from high-attention processing" and provide some time for all the interlocutors involved to orientate the next step of the discourse.

An example of rephrasing/self-repair may be seen when S2 (1. 20) corrects himself and rephrases the question he is about to ask, by replacing the personal pronoun in favour of the possessive pronoun ('his').

$$
20 \text { S2: was he was his name [last name2]? (.) }
$$

From the reflection on this short extract, several are the communicative strategies and skills used in order to negotiate meaning and achieve effective communication, be it in lingua franca situations in English, or with any other language. As has been pointed out, these strategies represent anything 
but failed, incoherent, and defective language use. Contrary to written language, where there is time for reflection and preparation, in oral speech, interlocutors must measure and adjust their speech accordingly at the specific moment. As a result, intercultural sensitivity is constantly required in any given context, especially when involving interactions with people from various backgrounds. From an EFL perspective this is a feature often neglected in comparison to correct grammar use. But it is no less important, as it is a quality not generally experienced by many mono- or even bilingual speakers, while stressed from an ELF point of view.

\section{Conclusion}

As has been discussed, EFL is traditionally seen as a subject taught at school, aiming at native speaker standards and culture as the ultimate target to be achieved, not only in terms of communication, but also in what concerns assessment. These aims may be acceptable for those who wish to go study/live in an English-speaking environment or for those who will go on to work with native speaker colleagues/clients. In most cases, however, many Expanding circle language users will most likely employ English with other non-native speakers in contexts other than in English-speaking countries. In the latter case, simply mastering native English standards does not necessarily guarantee effective and successful communication, quite the contrary. The reason for this lies in the fact that in many EFL classes the focus tends to be on achieving certain measured standards, forgetting other essential communicative skills and strategies vital for international and intercultural contexts.

Even though ELF communication may be typically characterized by its participants having to contend with the lack of shared knowledge and assumptions, and with different varieties of English and levels of competence, all of which may increase the risk of misunderstanding, Meierkord (2000) describes ELF use as actually being supportive. This is because users of ELF tend to be helpful, rather than centring their attention on each other's weak points. In fact, in real life interactions, the occurrence of misunderstandings and of miscommunication in intercultural ELF communication is not as common as may initially be thought, and the misunderstandings that do arise cannot be particularly ascribed to the participants' cultural background (Kaur 2011; Mauranen 2006). Reconsidering these facts then, ELF may be viewed as "a form of intercultural communication characterized by cooperation rather than misunderstanding" (Meierkord 2000, 11).

Canagarajah (2007) explains how proficient speakers of ELF share a number of different competencies. For instance, in addition to grammatical competence, ELF users also share language awareness, which allows them to read and deduce the norms and standards of the other multilingual participants, strategic competence, in order to successfully negotiate meaning in interpersonal interactions, and pragmatic competence for adopting the appropriate communicative practices, keeping in mind the participant, intention, and situation in question. Regarding the lack of pragmatic competence, if the conditions do not conform to the established conventions, this may lead to severe communicative issues, which may consequently result in undesirable reactions from the listener.

Taking into account all these issues and the increase in exchanges between people from different cultural groups, currently there is a growing demand for courses that enhance intercultural communicative competence and that increase intercultural awareness, so learners can develop added/different skills and competences. The simple example given here taken from the VOICE corpus (among the many other recordings available in the corpus) helps illustrate not only the 
widespread use of English around the world, but also provides a description of the linguistic features that may likely have a significant impact on the way ELT aims may be defined, consequently preparing learners for everyday real life situations.

It is only by considering language in context and in contact with several interlocutors and with the choices that are made that the transformations language undergoes can be observed. Consequently, this reality will undoubtedly have an effect not only on how people communicate, but also on traditional ELT approaches. In the latter case in particular, it can be concluded that more attention is now being given - and should continue to be given - to achieving intercultural communicative competence, which has an important impact on how students communicate once they leave school and enter the real world.

\section{References}

Berns, Margie. 2006. "World Englishes and Communicative Competence." In The Handbook of World Englishes, edited by Braj Kachru, Yamuna Kachru, and Cecil L. Nelson, 718-30. Malden: Blackwell.

Canagarajah, A. Suresh. 2005. Introduction to Reclaiming the Local in Language Policy and Practice, edited by A. Suresh Canagarajah, xiii-xxx. Mahwah: Lawrence Erlbaum.

—. 2007. "Lingua Franca English, Multilingual Communities and Language Acquisition." The Modern Language Journal 91 (Focus Issue): 923-39. doi:10.1111/j.1540-4781.2007.00678.x.

Erling, Elizabeth. 2004. "Globalization, English and the German University Classroom: A Sociolinguistic Profile of Students of English at the Freie Universität Berlin.” PhD Diss., University of Edinburgh.

Firth, Alan. 2006. "The Discursive Accomplishment of Normality: On 'Lingua Franca' English and Conversation Analysis.” Journal of Pragmatics 26 (2): 237-59. doi:10.1016/0378-2166(96)00014-8.

Firth, John R. 1930. Speech. London: Benn’s Sixpenny Library.

Gardner, Rod. 2001. When Listeners Talk: Response Tokens and Listener Stance. Amsterdam: John Benjamins.

Graddol, David. 2006. English Next. London: British Council. Accessed April 15, 2015. http://www. britishcouncil.org/learning-research-english-next.pdf.

Halliday, Michael. 1978. Language as Social Semiotic: The Social Interpretation of Language and Meaning. London: Arnold.

Halliday, Michael, and Ruqaiya Hasan. 1976. Cohesion in English. London: Longman.

Halliday, Michael, and Christian Matthiessen. 2004. An Introduction to Functional Grammar, 3rd ed. London: Arnold.

Hülmbauer, Cornelia, Heike Böhringer, and Barbara Seidlhofer. 2009. "Introducing English as a Lingua Franca (ELF): Precursor and Partner in Intercultural Communication." In Enseigner - apprendre - utiliser le français langue internationale en Europe aujourd'hui: pour une perspective comparatiste. Synergies Europe 3/09, edited by Chantal Cali, Martin Stegu, and Eva Vetter, 25-36. Accessed April 15, 2015. http://gerflint.fr/Basel Europe3/hulmbauer.pdf.

Hymes, Dell. 1962. "The Ethnography of Speaking." In Anthropology and Human Behavior, edited by Thomas Gladwin and William C. Sturtevant, 13-53. Washington: Anthropological Society of Washington.

—. 1972. "On Communicative Competence." In Sociolinguistics: Selected Readings, edited by John B. Pride and Janet Holmes, 269-85. Harmondsworth: Penguin.

—. 1980. Language in Education: Ethnolinguistic Essays. Washington: Center for Applied Linguistics.

Jenkins, Jennifer. 2000. The Phonology of English as an International Language. Oxford: Oxford University Press. 
—. 2007. English as a Lingua Franca: Attitudes and Identity. Oxford: Oxford University Press.

—. 2011. "Accommodating (to) ELF in the International University." Journal of Pragmatics 43 (4): 926-36. doi:10.1016/j.pragma.2010.05.011.

Kachru, Braj. 1985. "Standards, Codification and Sociolinguistic Realism: The English Language in the Outer Circle." In English in the World: Teaching and Learning the Language and Literatures, edited by Randolph Quirk and Henry G. Widdowson, 11-30. Cambridge: Cambridge University Press.

Kaur, Jagdish. 2011. "Intercultural Communication in English as a Lingua Franca: Some Sources of Misunderstanding." Intercultural Pragmatics 8 (1): 93-116. doi:10.1515/IPRG.2011.004.

Mauranen, Anna. 2005. “English as Lingua Franca: An Unknown Language?” In Identity, Community, Discourse. English in Intercultural Settings, edited by Giuseppina Cortese and Anna Duszak, 269-93. Bern: Peter Lang.

—. 2006. "Signalling and Preventing Misunderstanding in English as Lingua Franca Communication." International Journal of the Sociology of Language 177:123-50. doi:10.1515/IJSL.2006.008.

—. 2012. Exploring ELF: Academic English Shaped by Non-Native Speakers. Cambridge: Cambridge University Press.

Mauranen, Anna, and Elina Ranta, eds. 2009. English as a Lingua Franca. Studies and Findings. Newcastle upon Tyne: Cambridge Scholars.

Meierkord, Christiane. 2000. "Interpreting Successful Lingua Franca Interaction - An Analysis of Non-Native-/ Non-Native Small Talk Conversations in English.” Linguistik Online 5 (1/100). Accessed April 15, 2015. http://www.linguistik-online.com/1 00/MEIERKOR.HTM.

Nunn, Roger. 2007. "Redefining Communicative Competence for International and Local Communities." Journal of English as an International Language 2:7-49.

Pennycook, Alastair. 1999. "Pedagogical Implications of Different Frameworks for Understanding the Global Spread of English." In Teaching and Learning English as a Global Language: Native and Non-Native Perspectives, edited by Claude Gnutzmann, 147-55. Tübingen: Stauffenburg.

Perrett, Gillian. 2000. “Researching Second and Foreign Language Development.” In Researching Language in Schools and Communities: Functional Linguistic Perspectives, edited by Len Unsworth, 87-110. London: Cassell.

Scollon, Ron, and Suzanne Wong Scollon, 2001. Intercultural Communication: A Discourse Approach, 2nd ed. Malden: Blackwell.

Seidlhofer, Barbara. 2002. “Habeas Corpus and Divide et Impera: 'Global English’ and Applied Linguistics.” In Unity and Diversity in Language Use, edited by Kristyan Spelman Miller and Paul Thompson, 198-217. New York: Continuum.

-. 2003. A Concept of International English and Related Issues: From 'Real English' to 'Realistic English'? Strasbourg: Council of Europe. Accessed April 15, 2015. http://www.coe.int/t/dg4/linguistic/Source/SeidlhoferEN.pdf.

-. 2011. Understanding English as a Lingua Franca. Oxford: Oxford University Press.

Stenström, Anna-Brita. 1994. An Introduction to Spoken Interaction. Harlow: Longman.

Tannen, Deborah. 1989. Talking Voices: Repetition, Dialogue, and Imagery in Conversational Discourse. Cambridge: Cambridge University Press.

VOICE. Vienna-Oxford International Corpus of English. 2005-2013. Accessed July 6, 2011. www.univie.ac.at/ voice.

Widdowson, Henry G. 1994. “The Ownership of English.” TESOL Quarterly 28 (2): 377-89. doi: $10.2307 / 3587438$. 